\title{
Pengaruh Desain Kotak Terhadap Produktivitas Lebah Trigona sp
}

\section{The Effect of Stup Design on the Productivity of Trigona sp Honey Bee}

\author{
Erwan, Dwi K. Purnamasari*, W. Agustin \\ Fakultas Peternakan, Universitas Mataram \\ Jl. Majapahit 62 Mataram NTB. Telp/Fax: 0370-633603/640592 \\ *corresponding author,email: emmadkp03@gmail.com
}

Manuscript received: 15-09-2020. Accepted: 27-10-2020

\begin{abstract}
ABSTRAK
Salah satu faktor yang mempengaruhi produktivitas lebah madu adalah faktor temperatur dan kelembapan dari sarang atau kotak tempat hidup lebah. Sarang atau kotak yang yang temperatur dan suhunya terjaga akan memberikan kenyamanan lebah untuk hidup. Penelitian ini bertujuan untuk mengetahui pengaruh desain kotak terhadap produktivitas lebah Trigona sp. Penelitian menggunakan Rancangan Acak Lengkap (RAL) dengan 3 perlakuan desain kotak yaitu: Horizontal, Vertikal dan Medium. Setiap ukuran desain kotak terdiri dari 4 ulangan, dan setiap ulangan terdiri dari 2 kotak. Parameter yang diamati adalah jumlah sel anakan, jumlah pot polen, berat polen, jumlah pot madu, dan volume madu. Data di analisis menggunakan analisis varians (ANOVA) dan uji lanjut Duncan pada taraf kepercayaan $95 \%$. Hasil analisis menunjukkan bahwa kotak medium menghasilkan produksi sel anakan, jumlah polen, berat polen, jumlah pot madu dan volume madu lebah Trigona $s p$ lebih tinggi secara signifikan $(\mathrm{P}<0.05)$ dibandingkan desain vertikal dan horizontal. Kesimpulan dari penelitian ini bahwa kotak medium lebih baik digunakan dalam budidaya lebah Trigona sp.
\end{abstract}

Kata kunci : horizontal; vertical; medium; sel anakan; polen; madu

\begin{abstract}
One of the factors that effect the productivity of honey bees is the factor of temperature and humidity of the nest or stup where the bees live. A nest or stup with a maintened temperature and humidity will provide the bee comfort for live. This study discusses the effect of stup size design on the productivity honey bee of Trigona sp. This study used a Complete Random Design (CRD) with 3 stup design, namely: Horizontal, Vertical and Medium. Each design size consists of 4 replications, and each replication consists of 2 stup. Data were analyzed using by analysis of variance (ANOVA) and Duncan's test at $95 \%$ confidence level. The parameters observed were number of egg cells and pollen, weight pollen, number of honey pots and volume of honey. The results of the analysis showed that production of the medium design for number of egg cells, pollen, weight pollen, number of honey pots and the volume of honey of Trigona $s p$ was significantly higher than vertical and
\end{abstract}


horizontal design. The conclusion of this study showed that the medium stup is better used in farming system of Trigona sp.

Keywords: horizontal; vertical; medium; egg cell; pollen; honey

\section{PENDAHULUAN}

Indonesia memiliki potensi sumber daya alam yang tinggi dan berlimpah. Kekayaan yang terkandung di dalamnya sangat beraneka ragam terutama dari hasil hutan, baik berupa hasil hutan kayu (HHK) maupun hasil hutan bukan kayu (HHBK). Kekayaan sumber daya hutan mempunyai nilai ekonomi tinggi yang dapat menunjang kesejahteraan masyarakat. Salah satu produk hasil hutan bukan kayu diantaranya adalah lebah madu yang memiliki nilai guna dan ekonomi yang tinggi. Lebah madu diketahui mempunyai banyak kegunaan bagi kehidupan manusia dan memberikan manfaat tidak langsung maupun langsung. Manfaat tidak langsung yang dapat diperoleh dari budidaya lebah madu yaitu berkaitan dengan proses pelestarian sumberdaya hutan, peningkatan produktivitas tanaman dan adanya hubungan simbiosis yang saling menguntungkan. Manfaat langsung yang dapat diperoleh yaitu dihasilkannya berbagai produk lebah madu seperti madu, royal jelly, propolis, tepung sari, lilin, perekat dan racun lebah (Melissa, 2008).

Lebah madu dapat dibedakan menjadi dua yaitu lebah madu bersengat dan tidak bersengat (stingless bee). Salah satu jenis lebah madu tak bersengat adalah Trigona sp. Selain menghasilkan madu, dapat menghasilkan propolis dan bee polen (Murtidjo, 1991). Trigona sp menghasilkan madu dengan mengkonsumsi nektar dari bunga, dan memproduksi propolis dari mengkonsumsi getah serta memproduksi bee polen dari serbuk sari bunga (Riendriasari, 2013). Produksi madu dari lebah bergantung pada makanan yaitu tanaman yang tersedia di sekitar lebah. Pakan yang dikonsumsi Trigona sp merupakan salah satu faktor yang perlu diperhatikan dalam usaha pembudidayaannya, karena dari pakan dapat menentukan kualitas produk perlebahan yang dihasilkan (Bankova, 2005). Selain itu faktor lingkungan dan temperatur serta kelembaban dari sarang atau kotak lebah sangat mempengaruhi kenyamanan lebah untuk hidup.

Pembudidayaan lebah Trigona sp secara modern dipelihara menggunakan kotak (kotak lebah). Kotak memberikan keuntungan yang lebih baik karena pemeliharaan lebah madu dalam kotak akan mempermudah pengelolaan dan pemanenannya tanpa merusak koloni lebah madu. Kotak hendaknya terbuat dari bahan kayu dan tidak mudah terpengaruh oleh suhu udara, terutama perubahan dari panas kedingin atau sebaliknya. Ukuran dan posisi kotak juga sangat penting untuk diketahui, sebab ukuran dan posisi kotak sangat mempengaruhi produktifitas lebah Trigona sp dalam memproduksi produknya (Yanti, 2006).

Berdasarkan penjelasan di atas, maka perlu dilakukan penelitian untuk mengetahui perbandingan produk lebah Trigona $s p$ dari kotak vertikal, horizontal, dan medium, sehingga dapat diketahui jenis kotak yang terbaik serta metode yang tepat untuk menghasilkan produksi yang maksimal. 


\section{BAHAN DAN METODE}

Waktu dan Tempat Penelitian

Penelitian dilaksanakan pada bulan Agustus sampai Oktober 2019, di Desa Tengah, kecamatan Utan, kabupaten Sumbawa. Desa Tengah merupakan salah satu desa dari sembilan desa di Kecamatan Utan yang penduduknya sebagian besar bermata pencaharian petani. Hasil pertanian utama Desa Tengah adalah kopi, kemiri, kakao, dan kelapa, serta tanaman kayu lainnya.

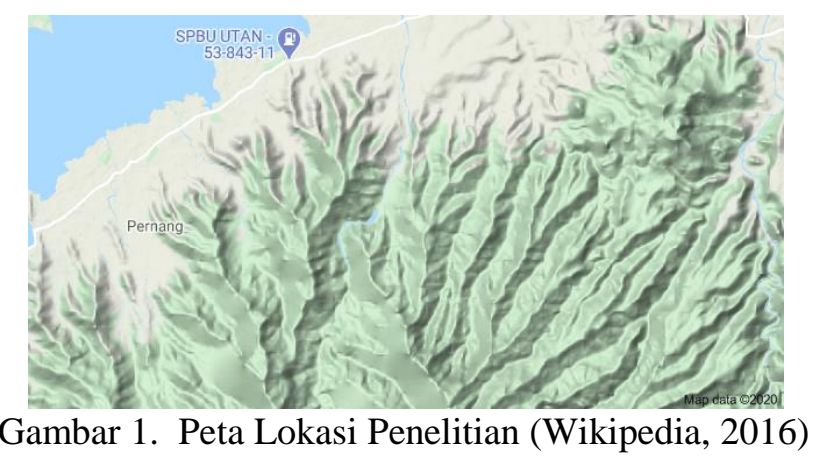

\section{Bahan Penelitian}

Materi yang digunakan pada penelitian ini adalah koloni lebah Trigona sp yang diperoleh dari kelompok ternak lebah Trigona sp di Desa Sabedo, Kecamatan Utan, Kabupaten Sumbawa. Koloni lebah ini hidup pada bibit kayu secara alami. Koloni lebah yang hidup pada bibit kayu lalu dipindahkan ke dalam kotak pemeliharaan lanjutan dengan desain horizontal, vertikal dan medium.

\section{Perlakuan dan Desain Percobaan}

Penelitian terdiri atas dua tahapan, yaitu tahap pertama adalah pemindahan koloni lebah yang berasal dari sarang awal (kayu) dipindahkan ke dalam kotak pemeliharaan (horizontal, vertikal, dan medium) sebanyak 24 kotak. Sarang awal koloni dibuka dengan cara membelah kayu menggunakan kapak atau gergaji. Lalu lebah ratu, seluruh koloni, seluruh telur, sebagian polen dan madu dipindahkan ke kotak pemeliharaan secara perlahan. Kotak ditutup, kemudian ditempelkan lem getah propolis dari sarang awal (kayu) pada lubang pintu agar lebah mengenali kotak barunya. Sarang awal diletakkan berdekatan dengan kotak baru dan dibiarkan beberapa saat sampai semua lebah pekerja berpindah ke kotak. Pemindahan koloni dilakukan pada sore hari, agar semua koloni lebah lebih cepat masuk ke dalam kotak baru.

Selanjutnya dilakukan tahapan kedua yaitu tahapan pemeliharaan lebah dalam kotak 3 perlakuan (horizontal, vertikal, dan medium). Masing-masing perlakuan terdiri dari 4 kotak ulangan dan setiap ulangan terdiri dari 2 unit kotak, sehingga seluruh kotak berjumlah 24 kotak. Setelah semua lebah pekerja dipindahkan ke kotak, lalu kotak ditempatkan pada lokasi dengan ketinggian $1.5 \mathrm{~m}$ dari permukaan tanah. Jarak antara kotak satu dengan kotak lainnya $0.5 \mathrm{~m}$ dan kotak ditempatkan secara acak. Pengamatan terhadap parameter produksi madu lebah dilakukan selama dua bulan. 


\section{Parameter yang diamati}

Parameter yang diamati dalam penelitian ini adalah:

1. Jumlah sel anakan, dihitung setiap dua minggu sekali.

2. Jumlah pot polen, dihitung setiap dua minggu sekali.

3. Jumlah pot madu, dihitung setiap dua minggu sekali.

4. Berat polen, dihitung dengan mengambil tiga jenis polen terbesar, sedang, dan terkecil, kemudian ditimbang menggunakan timbangan dengan kapasitas $200 \mathrm{~g}$ dengan kepekaan $0,1 \mathrm{~g}$.

5. Volume madu, dihitung dengan mengambil tiga jenis pot madu yang terbesar, sedang dan yang terkecil menggunakan pipet. Kemudian ketiga pot dihitung volume madu untuk mendapatkan rataan volume madu per pot. Selanjutnya rataan volume madu per pot dikalikan dengan jumlah pot yang ada dalam setiap kotak.

\section{Analisis Data}

Data yang terkumpul ditabulasi lalu dianalisis dengan menggunakan analisis ANOVA berdasarkan Rancangan Acak Lengkap 3x4x2 dan uji lanjut Duncan pada taraf kepercayaan $95 \%$.

\section{HASIL DAN PEMBAHASAN}

Koloni lebah Trigona sp. adalah koloni dari alam atau hutan yang bersarang pada tanaman kayu atau batang pohon yang berada di hutan. Pakan lebah yang ada di hutan Desa Sabedo adalah mangga, kelapa, asam, pohon nangka, kelat merah, kayu jawa dan beberapa jenis leguminosa. Jenis pohon tempat lebah bersarang yaitu cenderung pada pohon kelat merah dan kayu jawa. Peternak kemudian memanfaatkan lebah yang bersarang di hutan untuk dibudidayakan secara modern dengan cara menebang batang pohon tempat lebah bersarang, lalu ditempatkan pada lingkungan yang baru untuk dipelihara.

Pada penelitian ini dilakukan pemindahan koloni dari sarang asal ke dalam kotak penelitian dengan cara membelah batang pohon sarang awal, kemudian telur beserta polen dan madu dipindahkan ke dalam kotak pemeliharaan. Pemindahan dilakukan pada sore hari setelah semua koloni kembali ke sarang. Pemindahan koloni lebih mudah dilakukan dengan cara memindahkan ratunya terlebih dahulu, ketika ratunya sudah berpindah, maka secara otomatis anggota koloni akan mengikuti ratu untuk berpindah tempat. Setelah semua koloni berpindah, sarang kayu diletakkan di gazebo atau berugak dengan ketinggian 1,5 $\mathrm{m}$ di atas permukaan tanah, kemudian sarang asal di dekatkan dengan kotak yang baru agar koloni mengetahui tempat barunya.

Tahap awal yang dilakukan oleh lebah Trigona sp. adalah menutup semaksimal mungkin lubang yang ada di dalam kotak baru dengan menggunakan propolis. Disamping itu, peternak juga harus menandai pintu keluar masuk lebah menggunakan propolis. Jika sarang sudah tertutup rapat, Trigona $s p$. mulai memproduksi madu dan polen. Trigona $s p$. akan melakukan aktifitas keluar masuk kandang untuk mencari pakan yang berasal dari tanaman di sekitar kandang.

Pakan merupakan kebutuhan yang sangat penting bagi keberlanjutan peternakan lebah madu. Kekurangan pakan merupakan masalah yang sangat serius dan dapat menghambat perkembangan usaha peternakan lebah madu yang berdampak pada penurunan produksi madu, polen dan royal jeli, sehingga dapat menurunkan pendapatan peternak lebah. 
Selain itu, kekurangan pakan dapat menyebabkan koloni lebah madu menjadi lemah dari segi jumlah, lebah pekerja sedikit, produksi madu, polen dan royal jeli rendah, produktivitas lebah ratu menurun karena kurangnya pasokan pakan nektar dan polen sebagai sumber karbohidrat dan protein menyebabkan produksi lebah ratu sangat lambat.

Aktivitas lebah Trigona sp dalam mencari pakan (nektar, polen, dan resin) dipengaruhi oleh tersedianya pakan pada lokasi pembudidayaan. Lebah lebih banyak mengambil polen pada pagi hari yang disimpan pada kantong kaki belakang lebah, sedangkan pengambilan resin kebanyakan pada siang hari. Menurut Sumoprastomo (1980), pada waktu matahari terbit hingga pukul 08.00, bunga banyak mengeluarkan nektar sehingga pada waktu tersebut banyak lebah yang mencari nektar. Berdasarkan pada hasil pengamatan di lapangan, didapatkan sepuluh jenis tanaman yang teridentifikasi sebagai pakan lebah Trigona sp, tersaji pada Tabel 1.

Tabel 1. Jenis Tanaman Pakan Lebah pada Lokasi Penelitian

\begin{tabular}{clcc}
\hline No. & \multicolumn{1}{c}{ Tanaman } & Nama Ilmiah & $\begin{array}{c}\text { Sumber Pakan } \\
\text { ( Nektar/ Polen) }\end{array}$ \\
\hline 1 & Asam jawa & Tamarindus indica & Nektar \\
2 & Alpukat & Persea Americana & Nektar/Polen \\
3. & Bunga kamboja & Plumeria & Nektar \\
4. & Bunga pukul Sembilan & Turnera & Nektar \\
5. & Cabe merah & Capsicum annum & Nektar/Polen \\
6. & Jambu biji & Psidium guajava & Nektar/Polen \\
7. & Kapuk randu & Ceiba pentandra & Nektar/Polen \\
8. & Kumis kucing & Orthosiphon aristatus & Nektar \\
9. & Mangga & Mangifera indica & Nektar \\
10. & Pisang & Musa paradiciaca & Nektar/Polen \\
11. & Pepaya & Carica papaya & Nektar/Polen \\
12. & Srikaya & Annona squamosa & Nektar \\
\hline
\end{tabular}

Keterangan: * Yoppy, G. (2013).

Umumnya tanaman yang terdapat pada lokasi penelitian merupakan tanaman penghasil nektar, sedangkan tanaman penghasil polen hanya tujuh jenis (Alpukat, cabe merah. Jambu biji, kapuk randu, pisang dan pepaya). Tanaman-tanaman penghasil polen dan nektar, merupakan tanaman yang dibutuhkan lebah sebagai pakan. Polen dan nektar yang dihasilkan oleh tanaman dipergunakan lebah untuk memproduksi madu, polen dan royal jeli. Untuk itu dalam usaha budidaya madu, lokasi yang digunakan harus dipastikan terlebih dahulu terdapat tanaman-tanaman penghasil polen dan nektar, karena apabila lebah kekurangan pakan maka dapat menyebabkan koloni lebah madu menjadi lemah dari segi jumlah, lebah pekerja sedikit, produksi madu, polen dan royal jeli rendah, produktivitas lebah ratu menurun karena kurangnya pasokan pakan nektar dan polen sebagai sumber karbohidrat dan protein rendah.

Banyaknya tanaman-tanaman dalam lokasi budidaya madu juga akan mempengaruhi temperatur atau suhu dan kelembaban lingkungan. Suhu dan kelembaban lingkungan akan mempengaruhi aktivitas lebah dalam mencari pakan. Meningkatnya temperatur lingkungan menyebabkan aktivitas lebah dalam mencari pakan menurun karena lebah secara naluriah sudah dapat memperhitungkan bahwa pada suhu yang semakin tinggi maka energi yang dibutuhkan untuk terbang mencari pakan semakin besar, sedangkan nektar yang merupakan sumber energi hanya sedikit ketersediaannya di alam (Gojmerac, 1983). 


\section{Perkembangan Jumlah Sel Anakan}

Perkembangan jumlah sel anakan merupakan salah satu parameter penting untuk mengetahui keberlanjutan hidup dan produktifitas dari koloni lebah. Pengamatan perkembangan jumlah sel anakan dilakukan dengan mengitung jumlah sel anakan pada setiap kotak setiap dua minggu sekali secara hati-hati agar tidak mengganggu kenyamanan hidup koloni lebah. Hasil pengamatan jumlah sel anakan pada tiga kelompok desain kotak (horizontal, vertikal, dan medium) setiap dua minggu dalam waktu dua bulan disajikan pada Tabel 2.

Tabel 2. Perkembangan jumlah sel anakan setiap dua minggu

\begin{tabular}{lccccccc}
\hline \multirow{2}{*}{ Perlakuan } & \multicolumn{3}{c}{$\begin{array}{c}\text { Pertambahan jumlah sel anakan } \\
\text { (ekor/dua minggu) }\end{array}$} & \multirow{2}{*}{$\begin{array}{c}\text { Jumlah } \\
\text { (ekor) }\end{array}$} & $\begin{array}{c}\text { Rataan } \\
\text { (ekor) }\end{array}$ & $\begin{array}{c}\text { Standar } \\
\text { deviasi }\end{array}$ \\
\cline { 2 - 5 } & I & II & III & IV & & & \\
\hline Medium & 200.00 & 227.50 & 148.75 & 218.75 & 795.00 & $198.75^{\mathrm{c}}$ & 35.25 \\
Horizontal & 46.25 & 150.00 & 133.75 & 141.25 & 471.25 & $117.81^{\mathrm{b}}$ & 48.17 \\
Vertikal & 0 & 62.50 & 76.25 & 60.00 & 198.75 & $49.69^{\mathrm{a}}$ & 33.89
\end{tabular}

Keterangan: $\quad$ Huruf yang berbeda pada kolom yang sama menunjukkan berbeda nyata $(\mathrm{P}<0.05)$.

Kotak medium mengalami pertambahan jumlah sel anakan setiap dua minggu. Pada dua minggu pertama bertambah sebesar 200.00 ekor, kemudian bertambah 227.50 ekor pada dua minggu kedua, begitupun di dua minggu ketiga bertambah 148.75 ekor, seterusnya hingga dua minggu terakhir mengalami pertambahan sebesar 218.75 ekor sehingga berjumlah mencapai 795.00 ekor sel anakan. Begitupun pada kotak horizontal mengalami pertambahan jumlah koloni setiap dua minggu, dari dua minggu pertama bertambah sebesar 46.25 ekor, kemudian dua minggu kedua 150.00 ekor, seterusnya mengalami pertambahan hingga berjumlah 471.25 ekor sel anakan. Berbeda dengan kotak vertikal dimana pada dua minggu pertama tidak terdapat pertambahan koloni, namun pada dua minggu kedua mengalami pertambahan sebesar 62.5 ekor, begitupun pada minggu ketiga berjumlah 76.25 ekor, hingga minggu terakhir sebesar 60.00 ekor, sehingga perkembangan jumlah sel anakan pada kotak vertikal berjumlah 198.75 ekor. Berdasarkan rataan dari jumlah perkembangan sel anakan, kotak medium menghasilkan perkembangan jumlah sel anakan yang lebih tinggi secara signifikan $(\mathrm{P}<0.05)$ dibanding kotak horizontal dan vertikal. Begitupun pada kotak horizontal mengalami peningkatan yang lebih tinggi secara signifikan $(\mathrm{P}<0.05)$ dibanding kotak vertikal.

Perkembangan jumlah sel anakan yang tinggi pada kotak medium disebabkan karena faktor suhu dari setiap kotak, dimana suhu pada kotak medium $\left(25^{\circ} \mathrm{C}\right)$ merupakan suhu nyaman lebah di dalam sarang, dikarenakan ketika suhu di bawah $18^{\circ} \mathrm{C}$ dan diatas $30^{\circ} \mathrm{C}$ maka produktifitas lebah berkurang (Hilario et al., 2003). Pada kotak vertikal memiliki suhu lebih rendah yaitu $15^{\circ} \mathrm{C}$, sehingga lebah menjaga suhu tubuhnya dengan cara membentuk gerombolan untuk menghangatkan tubuhnya, sehingga aktifitas mencari pakan berkurang, yang mengakibatkan produktifitas lebah berkurang. Demikian halnya dengan kotak horizontal juga dipengaruhi oleh suhu, namun kotak horizontal memiliki suhu lebih tinggi 
dari kotak lainnya yaitu mencapai $34^{\circ} \mathrm{C}$. Ketika suhu ruang di atas $30^{\circ} \mathrm{C}$, lebah cenderung beraktifitas mengumpulkan air untuk mencairkan madu sehingga kelembaban udara di dalam kotak menjadi tinggi, akibatnya produktifitas semakin rendah.

\section{Perkembangan Jumlah Pot Polen}

Pengamatan jumlah pot polen dengan tiga ukuran kotak setiap dua minggu dalam waktu dua bulan. Hasil perkembangan pot polen disajikan pada Tabel 3 .

Tabel 3. Perkembangan jumlah pot polen setiap dua minggu.

\begin{tabular}{lccccccc}
\hline \multirow{3}{*}{ Perlakuan } & \multicolumn{9}{c}{ Jumlah pot } & & & \\
& polen/butir/dua minggu & Jumlah & Rata-rata & Standar deviasi \\
\cline { 2 - 5 } & I & II & III & IV & & & \\
\hline Medium & 2.50 & 8.75 & 3.63 & 3.50 & 18.38 & $4.59^{\mathrm{b}}$ & 2.82 \\
Horizontal & 1.88 & 2.25 & 2.38 & 2.13 & 8.63 & $2.16^{\mathrm{a}}$ & 0.21 \\
Vertikal & 1.13 & 2.13 & 2.50 & 2.63 & 8.38 & $2.09^{\mathrm{a}}$ & 0.68 \\
\hline
\end{tabular}

Keterangan: Huruf yang berbeda pada kolom yang sama menunjukkan berbeda nyata $(\mathrm{P}<0.05)$.

Aktifnya lebah dalam mencari pakan dilihat dari sehat tidaknya koloni di dalam kotak serta jumlah perkembangan sel anakan setiap dua minggu. Pada penelitian ini, kotak medium merupakan kotak tertinggi dalam pertambahan jumlah sel anakan, sehingga pada perkembangan jumlah pot polen cenderung lebih tinggi secara signifikan dibandingkan kotak lainnya.

Kotak medium pada dua minggu pertama bertambah sebesar 2.50 pot polen, kemudian pada dua minggu kedua meningkat dengan jumlah 8.75 pot polen, seterusnya hingga minggu terakhir meningkat 3.50 pot polen. Kotak horizontal juga mengalami peningkatan setiap minggunya, pada dua minggu pertama berjumlah 1.88 pot polen dilanjutkan pada dua minggu kedua berjumlah 2.25, dan pada dua minggu ketiga berjumlah 2.38 pot polen dan dua minggu terakhir terdapat 2.13 pot polen, sehingga mencapai jumlah sebesar 2.16 pot polen. Begitupun pada kotak vertikal mengalami peningkatan dari minggu pertama berjumlah 1.13 pot polen, dan seterusnya hingga minggu terakhir berjumlah 8.38 pot polen, sehingga jumlah keseluruhan mencapai 2.09 pot polen.

Pengaruh lingkungan terhadap intensitas pengumpulan polen dapat mempengaruhi secara langsung dan tidak langsung. Secara langsung dapat mempengarui aktivitas terbang, tingkat dan pola konsumsi. Secara tidak langsung dapat mepengaruhi produksi polen bunga. Temperatur lingkungan sangat mempengaruhi jumlah konsumsi pakan lebah madu, dan dengan demikian akan mempengaruhi tingkat pengumpulan pakan (polen dan nektar) dari tanaman. Kelembaban, temperatur, kecepatan angin, dan intensitas cahaya berpengaruh sangat nyata terhadap aktivitas terbang lebah (Sihombing, 2005).

Perkembangan yang lambat pada kotak vertikal dan horizontal disebabkan karena koloni pada kedua kotak tersebut kurang sehat dan kurang aktif mencari pakan, dilihat dari aktivitas lebah keluar masuk kotak untuk mencari pakan sangat kurang, disebabkan karena faktor lingkungan dengan suhu yang sangat tinggi dengan kisaran $18-34^{\circ} \mathrm{C}$, sedangkan suhu 
ideal lebah terbang adalah $16-26^{\circ} \mathrm{C}$ (Hilario et al., 2003), sehingga koloni di dalam kotak memanfaatkan madu dan polen sebagai pakan di dalam sarang. Hal ini yang menyebabkan berkurangnya perkembangan polen dan madu.

\section{Perkembangan Jumlah Pot Madu}

Hasil pengamatan jumlah pot madu dengan tiga ukuran kotak (Horizontal, vertikal, dan medium) setiap dua minggu dalam waktu dua bulan disajikan pada Tabel 4.

Tabel 4. Perkembangan jumlah pot madu setiap dua minggu

\begin{tabular}{|c|c|c|c|c|c|c|c|}
\hline \multirow{2}{*}{ Perlakuan } & \multicolumn{4}{|c|}{ Jumlah pot madu/ dua Minggu } & \multirow{2}{*}{ Jumlah } & \multirow{2}{*}{ Rata-rata } & \multirow{2}{*}{$\begin{array}{l}\text { Standar } \\
\text { deviasi }\end{array}$} \\
\hline & I & II & III & IV & & & \\
\hline Medium & 8.50 & 18.13 & 37.00 & 26.00 & 89.63 & $22.41^{b}$ & 12.08 \\
\hline Horizontal & 3.75 & 5.25 & 4.88 & 5.75 & 19.63 & $4.91^{\mathrm{a}}$ & 0.85 \\
\hline Vertikal & 0.63 & 4.63 & 4.75 & 8.88 & 18.88 & $4.72^{\mathrm{a}}$ & 3.37 \\
\hline
\end{tabular}

Keterangan : Huruf yang berbeda pada kolom yang sama menunjukkan berbeda nyata $(\mathrm{P}<0.05)$.

Perkembangan jumlah pot madu pada Tabel 4 tersebut menunjukkan bahwa kotak medium memilliki perkembagan jumlah pot madu lebih tinggi secara signifikan dari kotak lainnya yaitu mencapai rata-rata 22.41 pot madu, kotak horizontal rata-rata bejumlah 4.91 pot madu, sementara untuk kotak vertikal memiliki jumlah rata-rata lebih rendah yaitu 4.72 pot madu. Kotak medium pada dua minggu pertama bertambah 8.50 butir pot madu, kemudian meningkat pada dua minggu kedua sebesar 18,13 butir, terus meningkat hingga minggu terakhir berjumlah 89.63 butir pot madu. Begitupun kotak horizontal dan vertikal mengalami peningkatan setiap minggunya namun lambat. Aktivitas pencarian nektar, tepung sari dan air tergantung cuaca dan kebutuhan koloni. Lebah madu aktif mencari nektar dan tepung sari pada suhu kisaran $20-26^{\circ} \mathrm{C}$ (Gojmerac, 1983). Meningkatnya temperatur lingkungan menyebabkan aktivitas mencari pakan menurun karena lebah secara naluriah sudah dapat memperhitungkan bahwa pada suhu yang semakin tinggi maka energi yang dibutuhkan untuk terbang mencari pakan semakin besar, sedangkan nektar merupakan sumber energi hanya sedikit ketersediaannya di alam (Gojmerac, 1983). Aktivitas lebah madu pekerja akan menurun bila suhu lingkungan semakin panas. Peningkatan suhu lingkungan juga menyebabkan nektar dari bunga mengalami penguapan sehingga volume nektar menurun. Hal tersebut mengakibatkan kadar air nektar pada bunga berkurang, sehingga kadar gulanya mengalami peningkatan (Nugroho, 1993).

Peningkatan jumlah produksi madu dipengaruhi oleh pakan yang memiliki kandungan nektar. Lebah mengambil nektar di pagi hari pada pukul 08.00, karena pada pukul 07.00 lebah menghangatkan tubuhnya di depan kotak tepat pada sinar matahari. Diantara sekian banyak lebah pekerja ada yang hanya mengumpulkan nektar, ada juga yang mengumpulkan polen saja, tetapi ada juga yang mengambil polen dan nektar sekaligus (Morse dan Hooper, 1985). Banowu (2016) menjelaskan pada penelitiannya bahwa produksi kotak horizontal lebih rendah dibandingan dengan produksi kotak vertikal. Ini terlihat pada 
produk madu yaitu hanya berkisar $10.18 \%$ dibandingkan dengan perlakuan vertikal 20.16 $\%$ dari berat sarang,

\section{Berat Polen dan Volume madu}

Tabel 5. Hasil Penimbangan Berat Polen (g) dan Volume madu (ml)

\begin{tabular}{lcc}
\hline \multicolumn{1}{c}{ Perlakuan } & $\begin{array}{c}\text { Berat Polen } \\
(\mathrm{g})\end{array}$ & $\begin{array}{c}\text { Volume Madu } \\
(\mathrm{ml})\end{array}$ \\
\hline Medium & $3.37^{\mathrm{c}} \pm 2.45$ & $42.15^{\mathrm{a}} \pm 70.83$ \\
Horizontal & $1.95^{\mathrm{a}} \pm 1.76$ & $8.77^{\mathrm{b}} \pm 7.51$ \\
Vertikal & $2.66^{\mathrm{b}} \pm 1.70$ & $9.00^{\mathrm{b}} \pm 8.55$ \\
\hline Keterangan : Huruf yang berbeda pada kom
\end{tabular}

Keterangan : Huruf yang berbeda pada kolom yang sama menunjukkan berbeda nyata $(\mathrm{P}<0.05)$.

Rataan berat polen sebesar 1.95-3.37 g. Rataan tertinggi adalah pada kotak medium secara signifikan $(\mathrm{P}<0,05)$ dibandingkan kotak vertikal dan horizontal. Hal ini disebabkan pada perkembangan sel anakan, kotak medium rata-rata tertinggi secara signifikan dibandingkan kotak lainnya, sehingga dalam pencarian pakan (polen), koloni pada kotak medium cenderung lebih banyak yang mengakibatkan jumlah pot polen yang dihasilkan lebih tinggi. Pada kotak vertikal memiliki suhu lebih rendah yaitu $15^{\circ} \mathrm{C}$, sehingga lebah menjaga suhu tubuhnya dengan cara membentuk gerombolan untuk menghangatkan tubuhnya, sehingga aktifitas mencari pakan berkurang, yang mengakibatkan produktifitas lebah berkurang. Demikian halnya dengan kotak horizontal juga dipengaruhi oleh suhu, namun kotak horizontal memiliki suhu lebih tinggi dari kotak lainnya yaitu mencapai $34^{\circ} \mathrm{C}$. Ketika suhu ruang di atas $30^{\circ} \mathrm{C}$, lebah cenderung beraktifitas mengumpulkan air untuk mencairkan madu sehingga kelembapan udara di dalam kotak menjadi tinggi, akibatnya produktifitas semakin rendah, sehingga lebah kurang aktif mencari pakan dan bertahan hidup dengan cara memakan bubuk polen yang ada di dalam sarang.

Rataan volume madu berjumlah $8,77-42,15$. Rata-rata tertinggi adalah pada kotak medium secara signifikan $(\mathrm{p}<0,05)$ dibandingkan kotak vertikal dan horizontal. Hal ini disebabkan pada perkembangan sel anakan, kotak medium rata-rata tertinggi secara signifikan dibandingkan kotak lainnya, sehingga dalam pencarian pakan (nektar), koloni pada kotak medium cenderung lebih banyak yang mengakibatkan jumlah pot madu yang dihasilkan lebih tinggi, selain itu pada kotak vertikal memiliki suhu lebih rendah yaitu $15^{\circ} \mathrm{C}$, sehingga lebah menjaga suhu tubuhnya dengan cara membentuk gerombolan untuk menghangatkan tubuhnya, sehingga aktifitas mencari pakan berkurang, yang mengakibatkan produktifitas lebah berkurang. Demikian halnya dengan kotak horizontal juga dipengaruhi oleh suhu, namun kotak horizontal memiliki suhu lebih tinggi dari kotak lainnya yaitu mencapai $34^{\circ} \mathrm{C}$. Ketika suhu ruang di atas $30^{\circ} \mathrm{C}$, lebah cenderung beraktifitas mengumpulkan air dan bertahan hidup dengan cara mengkonsumsi cairan madu yang ada di dalam sarang. 


\section{KESIMPULAN}

Kotak dengan desain medium menghasilkan produksi madu lebah Trigona sp. yang lebih tinggi secara nyata dibandingkan desain kotak vertikal dan horizontal, nampak dari perkembangan jumlah sel anakan, pot polen, pot madu, berat polen, dan volume madu lebih tinggi secara signifikan. Kotak dengan desain medium direkomendasikan sebagai desain kotak terbaik untuk digunakan dalam usaha budidaya lebah Trigona sp.

\section{DAFTAR PUSTAKA}

Bankova V., 2005. Recent Strends and Important Developments in Propolis Research. eCAM 2(1): 29-32.

Banowu A., 2016. Studi Perkembangan Koloni dan Produksi Lebah Trigona sp dari Posisi Kotak Yang Berbeda. Skripsi. Program Studi Manajemen Hutan, Jurusan Kehutanan, Universitas Halu Oleo.

Gojmerac, W. L. 1983. Bee, Bee keeping, Honey and Pollination. Avi, Westport

Hilario, S. D., M. Girimenes, \& V. L. Imperatriz-Fonseca. 2003. The Influence of colony size in diel rhythms of flight activity of Melipona bicolor lepeletier (Hymenoptera, Apidae, Meliponini). In G.A R. Melo \& Alves-dos-Santos Apoidea Neotropica: Homenagem Aos de Jesus Santiago Moure. Editora UNESC, Criciúma.p:191-197

Melissa. 2008. Studi Pengembangan Hasil Hutan Bukan Kayu. Rajawali Press. Jakarta.

Morse, R. A. \& Hooper T. 1985. The Illustrated Encyclopedia of Beekeeping. Blandford Press, England.

Murtidjo, B.A. 1991. Memelihara Lebah Madu. Penerbit Kanisius, Yogyakarta.

Nugroho, M. 1993. Inventarisasi dan pemanfaatan tanaman pakan lebah di kawasan gunung Arca Sukabumi. Skripsi. Fakultas Peternakan, Institut Pertanian Bogor, Bogor.

Riendriasari, S.D. 2013. Budidaya Lebah Madu Trigona sp. Mudah dan Murah. Makalah Seminar Alih Teknologi "Budidaya Lebah Madu Trigona sp". Balai Teknologi Hasil Hutan Bukan Kayu. Mataram

Sihombing, D. T. H. 2005. Ilmu Ternak Lebah Madu. Gajah Mada University Press, Yogyakarta.

Sumoprastowo, R. M. \& R. A. Suprapto. 1980. Berternak Lebah Madu Modern. PT. Bhantara Niaga Media, Jakarta.

Wikipedia, 2016. Desa Tengah Kecamatan Utan Kabupaten Sumbawa. Wikipedia.org/wiki/Tengah_Utan_Sumbawa.

Yanti. I.G.P.D., 2006. Pengaruh Ukuran Kotak Terhadap Produk Lebah Trigona sp. Di Kecamatan Landono Kabupaten Konawe Selatan. Skripsi. Jurusan Kehutanan, Fakultas Kehutanan. UHO.

Yoppy, G. 2013. Aktivitas dan produktifitas lebah Trigona Laeviceps dii kebun polikultur dan monokultur pala (Myristica fragrans). Skripsi, Departemen Ilmu Produksi dan Teknologi Peternakan, Fakultas Peternakan, Universitas Pertanian Bogor. 